\title{
Article
}

\section{Prescribers' Knowledge, Attitudes and Behaviors on Antibiotics, Antibiotic Use and Antibiotic Resistance in Jordan}

\author{
Reema A. Karasneh ${ }^{1}\left(\mathbb{D}\right.$, Sayer I. Al-Azzam ${ }^{2}$, Mera Ababneh ${ }^{2}$, Ola Al-Azzeh ${ }^{3}$, Ola B. Al-Batayneh ${ }^{4}(\mathbb{D}$, \\ Suhaib M. Muflih ${ }^{2}{ }^{(D}$, Mohammad Khasawneh ${ }^{5}$, Abdo-Rahman M. Khassawneh ${ }^{6}$, Yousef S. Khader ${ }^{7}{ }^{\circ}$, \\ Barbara R. Conway 8,9 (i) and Mamoon A. Aldeyab ${ }^{8, *}$
}

Citation: Karasneh, R.A.; Al-Azzam, S.I.; Ababneh, M.; Al-Azzeh, O.; Al-Batayneh, O.B.; Muflih, S.M.; Khasawneh, M.; Khassawneh, A.-R.M.; Khader, Y.S.; Conway, B.R.; et al. Prescribers' Knowledge, Attitudes and Behaviors on Antibiotics, Antibiotic Use and Antibiotic Resistance in Jordan Antibiotics 2021, 10, 858. https:// doi.org/10.3390/antibiotics10070858

Academic Editor: Albert Figueras

Received: 22 June 2021

Accepted: 13 July 2021

Published: 15 July 2021

Publisher's Note: MDPI stays neutral with regard to jurisdictional claims in published maps and institutional affiliations.

Copyright: (c) 2021 by the authors. Licensee MDPI, Basel, Switzerland. This article is an open access article distributed under the terms and conditions of the Creative Commons Attribution (CC BY) license (https:// creativecommons.org/licenses/by/ $4.0 /)$.
1 Department of Basic Medical Sciences, Faculty of Medicine, Yarmouk University, Irbid 21163, Jordan; reema.karasneh@yu.edu.jo

2 Department of Clinical Pharmacy, Faculty of Pharmacy, Jordan University of Science and Technology, Irbid 22110, Jordan; salazzam@just.edu.jo (S.I.A.-A.); mababneh@just.edu.jo (M.A.); smmuflih@just.edu.jo (S.M.M.)

3 Department of Pharmacy Practice, College of Pharmacy, King Saud Bin Abdulaziz University for Health Sciences, Riyadh 11481, Saudi Arabia; azzeho@ksau-hs.edu.sa

4 Department of Preventive Dentistry, Faculty of Dentistry, Jordan University of Science and Technology, Irbid 22110, Jordan; olabt@just.edu.jo

5 Department of Pediatrics and Neonatology, Faculty of Medicine, Jordan University of Science and Technology, Irbid 22110, Jordan; deema321@just.edu.jo

6 Faculty of Medicine, Jordan University of Science and Technology, Irbid 22110, Jordan; aboodkhassawneh62@gmail.com

7 Department of Public Health, Faculty of Medicine, Jordan University of Science and Technology, Irbid 22110, Jordan; yskhader@just.edu.jo

8 Department of Pharmacy, School of Applied Sciences, University of Huddersfield, Huddersfield HD13DH, UK; b.r.conway@hud.ac.uk

9 Institute of Skin Integrity and Infection Prevention, University of Huddersfield, Huddersfield HD13DH, UK

* Correspondence: M.AlDeyab@hud.ac.uk; Tel.: +44-01484-472825

\begin{abstract}
More research is needed on the drivers of irrational antibiotic prescribing among healthcare professionals and to ensure effective prescribing and an adequate understanding of the issue of antibiotic resistance. This study aimed at evaluating prescribers' knowledge, attitudes and behaviors about antibiotic use and antibiotic resistance. A cross-sectional study was conducted utilizing an online questionnaire and included physicians and dentists from all sectors in Jordan. A total of 613 prescribers were included (physicians $n=409$, dentists $n=204$ ). Respondents' knowledge on effective use, unnecessary use or associated side effects of antibiotics was high ( $>90 \%)$, compared with their knowledge on the spread of antibiotic resistance (62.2\%). For ease of access to the required guidelines on managing infections, and to materials that advise on prudent antibiotic use and antibiotic resistance, prescribers agreed in $62 \%$ and $46.1 \%$ of cases, respectively. $28.4 \%$ of respondents had prescribed antibiotics when they would have preferred not to do so more than once a day or more than once a week. Among respondents who prescribed antibiotics, 63.4\% would never or rarely give out resources on prudent use of antibiotics for infections. The findings are of importance to inform antibiotic stewardships about relevant interventions aimed at changing prescribers' behaviors and improving antibiotic prescribing practices.
\end{abstract}

Keywords: attitudes; prescribers; antibiotics; physicians; dentists; antibiotics resistance

\section{Introduction}

Antimicrobial resistance (AMR) poses a significant problem to public health that threatens the provision of effective treatment for a range of infections and undermines the efforts to control the development and spread of multidrug-resistant (MDR) bacteria [1]. The development of AMR has been shown to lead to longer hospital stays, increased mortality and higher healthcare costs [1-3]. A review estimating the global economic cost 
of antimicrobial resistance, the $\mathrm{O}^{\prime} \mathrm{Neill}$ report, revealed that a continued rise in resistance would lead to 10 million people dying every year by 2050, resulting in projected costs as high as USD 100 trillion worldwide [2]. It is anticipated that the economic impact of AMR will be greatest in developing countries, leading to increasing economic inequality between countries [4]. In addition, maintaining antibiotic effectiveness is critical for the sustainability of modern healthcare systems. Common infections will be associated with more severe complications and an increased risk of death, and several fundamental healthcare processes could be unavailable or unsafe [5]. Therefore, actions are urgently needed to minimize the emergence of AMR. The link between antibiotic use and the development and spread of bacterial resistance has been demonstrated in several studies [1,2,6-9]. Studies suggest that between $25 \%$ and $50 \%$ of hospitalized patients receive antibiotics, of which approximately $20-50 \%$ of all antimicrobials prescribed are either unnecessary or inappropriately used [10-13]. The impact of the rapid evolution of resistance on reducing the potential for sustained efficacy of current classes of antibiotics, or newly developed antibiotics, highlights the importance of promoting appropriate antimicrobial prescribing practices $[14,15]$. In response to the growing threat of antimicrobial resistance, the World Health Assembly adopted a global action plan (GAP) on AMR [16].

Antibiotic prescribing is a complex process influenced by several factors including the healthcare system, physicians, other healthcare providers, patients and the general public [17]. A lack of understanding and clarity about prudent antimicrobial use, and the spread of antimicrobial-resistant microorganisms present important barriers to the prevention and control of AMR [18-20]. Since changes in antibiotic prescribing patterns will need changes in healthcare professionals' behavior, it is necessary to understand the key factors influencing their prescribing and what interventions may effect change. Therefore, the aim of this study was to evaluate prescribers' knowledge, attitudes and behaviors regarding antibiotics, antibiotic use and antibiotic resistance in Jordan, as one of the Middle East countries. Reports form Jordanian hospitals showed a high prevalence of AMR, with particular note to methicillin-resistant Staphylococcus aureus (MRSA) that reached a rate of $45 \%$ [21].

\section{Results}

\section{Prescribers' Sociodemographic Characterestics and Actual Knowledge}

Table 1 shows the characteristics of the respondents, with $71.0 \%$ being in the age group of $24-35$ years and more, and $64.1 \%$ of those participating in the study being male. Two thirds $(66.7 \%)$ of the study participants were medical doctors (physicians), and around half of the participants were generalists $(49.8 \%$ ) and providing care in a hospital setting (46.5\%).

Table 1. Respondents' sociodemographic characteristics $(n=613)$.

\begin{tabular}{cll}
\hline Variable & \multicolumn{1}{c}{ Frequency } & Percentage $\%$ \\
\hline Gender & Female: 220 & $35.9 \%$ \\
& Male: 393 & $64.1 \%$ \\
Age, years & $24-35: 435$ & $71.0 \%$ \\
& $36-55: 138$ & $22.5 \%$ \\
Profession & Medical Doctor (physician): 409 & $6.5 \%$ \\
& Dentist: 204 & $66.7 \%$ \\
Role of specialist & Specialist: 280 & $33.3 \%$ \\
& Generalist: 305 & $45.7 \%$ \\
& Academia/Research: 28 & $49.8 \%$ \\
Years of practice $(n)$ & $0-5: 376$ & $4.6 \%$ \\
& 6-15: 127 & $61.3 \%$ \\
& $\geq 16: 110$ & $20.7 \%$ \\
Place of practice & Public Clinic: 74 & $18.0 \%$ \\
& Academia / Research: 45 & $12.1 \%$ \\
& Hospital: 285 & $7.3 \%$ \\
& Private Clinic: 209 & $46.5 \%$ \\
& North: 288 & $34.1 \%$ \\
& Middle: 289 & $47.0 \%$ \\
Governorate (region) & South: 36 & $47.2 \%$ \\
& & $5.9 \%$ \\
\hline
\end{tabular}


More than $90 \%$ of the respondents correctly answered the questions on effective use, unnecessary use or associated side effects of antibiotics; however, lower percentages of correct answers were observed for questions on the spread of antibiotic resistance (Table 2).

Table 2. Respondents' actual knowledge.

\begin{tabular}{|c|c|c|c|}
\hline Key Knowledge Questions & Correct Answer & Answer & Percentage $\%$ \\
\hline \multirow{3}{*}{ Antibiotics are effective against viruses: } & False & False: 587 & $95.8 \%$ \\
\hline & & True: 16 & $2.6 \%$ \\
\hline & & Unsure: 10 & $1.6 \%$ \\
\hline \multirow{3}{*}{ Antibiotics are effective against cold infections: } & False & False: 559 & $91.2 \%$ \\
\hline & & True: 40 & $6.5 \%$ \\
\hline & & Unsure: 14 & $2.3 \%$ \\
\hline \multirow{3}{*}{$\begin{array}{l}\text { Unnecessary use of antibiotics makes them } \\
\text { become ineffective: }\end{array}$} & True & False: 33 & $5.4 \%$ \\
\hline & & True: 571 & $93.1 \%$ \\
\hline & & Unsure: 9 & $1.5 \%$ \\
\hline \multirow{3}{*}{$\begin{array}{l}\text { Taking antibiotics has associated side effects or risks } \\
\text { such as diarrhea, colitis, allergies: }\end{array}$} & True & False: 15 & $2.4 \%$ \\
\hline & & True: 574 & $93.6 \%$ \\
\hline & & Unsure: 24 & $3.9 \%$ \\
\hline \multirow{3}{*}{$\begin{array}{l}\text { Every person treated with antibiotics is at an increased } \\
\text { risk of antibiotic-resistant infection: }\end{array}$} & True & False: 80 & $13.1 \%$ \\
\hline & & True: 486 & $79.3 \%$ \\
\hline & & Unsure: 47 & $7.7 \%$ \\
\hline \multirow{3}{*}{$\begin{array}{l}\text { Antibiotic-resistant bacteria can spread from person } \\
\text { to person: }\end{array}$} & True & False: 159 & $25.9 \%$ \\
\hline & & True: 381 & $62.2 \%$ \\
\hline & & Unsure: 73 & $11.9 \%$ \\
\hline \multirow{3}{*}{ Healthy people can carry antibiotic-resistant bacteria: } & True & False: 75 & $12.2 \%$ \\
\hline & & True: 413 & $67.4 \%$ \\
\hline & & Unsure: 125 & $20.4 \%$ \\
\hline \multirow{3}{*}{$\begin{array}{l}\text { The use of antibiotics to stimulate growth in farm } \\
\text { animals is legal in Jordan: }\end{array}$} & False & False: 87 & $14.2 \%$ \\
\hline & & True: 86 & $14.0 \%$ \\
\hline & & Unsure: 440 & $71.8 \%$ \\
\hline
\end{tabular}

Knowledge average scores were found to be significantly higher among physicians $(p=0.0031)$, middle-age groups ( $36-55$ years) $(p=0.0140)$ and specialists $(p<0.0001)$ (Table 3$)$. Higher proportions of full scores were also found to be significantly higher among physicians $(p=0.0350)$, and more years of experience $(p=0.0183)$, as shown in Table 3.

Table 3. Predictors of actual knowledge scores among prescribers.

\begin{tabular}{|c|c|c|c|c|c|c|}
\hline Variable & & $\begin{array}{c}\text { No. of } \\
\text { Respondents }\end{array}$ & $\begin{array}{l}\text { Average Score } \\
\text { (Range 0-8) }\end{array}$ & $p$-Value & $\begin{array}{c}n(\%) \text { of Respondents } \\
\text { Who Answered } \\
\text { Correctly (Full Score) }\end{array}$ & $p$-Value \\
\hline \multirow{3}{*}{ Region: } & North & 288 & $5.9 \pm 1$ & \multirow{3}{*}{0.8182} & $14(2.3)$ & \multirow{3}{*}{0.1839} \\
\hline & Middle & 289 & $6.0 \pm 1.2$ & & $12(2.0)$ & \\
\hline & South & 36 & $6.0 \pm 0.95$ & & $0(0.0)$ & \\
\hline \multirow{2}{*}{ Profession: } & Physicians & 409 & $6.1 \pm 1.2$ & \multirow{2}{*}{0.0031} & $22(3.6)$ & \multirow{2}{*}{0.0350} \\
\hline & Dentists & 204 & $5.7 \pm 1.2$ & & $4(0.7)$ & \\
\hline \multirow{2}{*}{ Gender: } & Female & 220 & $5.9 \pm 1.2$ & \multirow{2}{*}{0.4818} & $10(1.6)$ & \multirow{2}{*}{0.7799} \\
\hline & Male & 393 & $5.9 \pm 1.2$ & & $16(2.6)$ & \\
\hline \multirow{3}{*}{ Age group: } & 24-35 years & 435 & $5.9 \pm 1.2$ & \multirow{3}{*}{0.0140} & $15(2.4)$ & \multirow{3}{*}{0.0185} \\
\hline & $36-55$ years & 138 & $6.2 \pm 1.2$ & & $11(1.8)$ & \\
\hline & $\geq 56$ years & 40 & $5.9 \pm 1.6$ & & - & \\
\hline \multirow{3}{*}{$\begin{array}{l}\text { Years in } \\
\text { practice: }\end{array}$} & $0-5$ years & 376 & $5.9 \pm 1.2$ & \multirow{3}{*}{0.0560} & $11(1.8)$ & \multirow{3}{*}{0.0183} \\
\hline & $6-15$ years & 127 & $6.0 \pm 1.3$ & & $5(0.8)$ & \\
\hline & $\geq 16$ years & 110 & $6.2 \pm 1.2$ & & $10(1.6)$ & \\
\hline \multirow{3}{*}{ Role: } & Academia/Research & 28 & $5.8 \pm 1.6$ & \multirow{3}{*}{$<0.0001$} & $2(0.003)$ & \multirow{3}{*}{0.0519} \\
\hline & Generalist & 305 & $5.7 \pm 1.2$ & & $6(1.0)$ & \\
\hline & Specialist & 280 & $6.3 \pm 1.1$ & & $18(2.9)$ & \\
\hline
\end{tabular}


Further, a multivariable stepwise regression model was conducted, and only profession and age were found to be statistically significant predictors of higher knowledge scores. The results of the univariate analysis are presented in Table 4. Physicians and respondents' score in the age group of 36-55 years had higher knowledge (estimate: 0.24 , CI: $0.12-0.34, p<0.0001$; estimate: 0.27 , CI: $0.09-0.37, p=0.0152$, respectively).

Table 4. Univariate analysis of the relationship between knowledge scores and demographic characteristics of respondents.

\begin{tabular}{|c|c|c|c|}
\hline Variable & Estimate & $95 \% \mathrm{CI}$ & $p$-Value \\
\hline $\begin{array}{l}\text { Gender } \\
\text { Female } \\
\text { Male* }\end{array}$ & -0.04 & $-0.14-0.07$ & 0.49190 \\
\hline $\begin{array}{l}\text { Region } \\
\text { Middle } \\
\text { North } \\
\text { South* }\end{array}$ & $\begin{array}{l}-0.03 \\
0.03\end{array}$ & $\begin{array}{l}-0.2-0.14 \\
-0.15-0.20\end{array}$ & $\begin{array}{l}0.73557 \\
0.77490\end{array}$ \\
\hline $\begin{array}{l}\text { Profession } \\
\text { Physician } \\
\text { Dentist* }\end{array}$ & 0.16 & $0.8-0.25$ & 0.00310 \\
\hline $\begin{array}{l}\text { Age group } \\
24-35 \text { years } \\
36-55 \text { years } \\
\geq 56 \text { years * }\end{array}$ & $\begin{array}{l}-0.11 \\
0.24\end{array}$ & $\begin{array}{l}-0.28-0.05 \\
0.05-0.18\end{array}$ & $\begin{array}{l}0.18090 \\
0.01670\end{array}$ \\
\hline $\begin{array}{l}\text { Years in practice } \\
\geq 16 \text { years } \\
6-15 \text { years } \\
0-5 \text { years } *\end{array}$ & $\begin{array}{l}0.18 \\
-0.03\end{array}$ & $\begin{array}{l}0.09-0.27 \\
-0.21-0.11\end{array}$ & $\begin{array}{l}0.04200 \\
0.67040\end{array}$ \\
\hline $\begin{array}{l}\text { Role } \\
\text { Specialist } \\
\text { Academic/Research } \\
\text { Generalist * }\end{array}$ & $\begin{array}{l}0.34 \\
-0.13\end{array}$ & $\begin{array}{l}0.15-0.41 \\
-0.44-0.18\end{array}$ & $\begin{array}{l}0.00140 \\
0.39820\end{array}$ \\
\hline
\end{tabular}

The results of perceived knowledge (Table 5) show that most of the respondents either agree or strongly agree that they know what antibiotic resistance is and what information to give to individuals about prudent use of antibiotics and antibiotic resistance, and that they have sufficient knowledge about how to use antibiotics appropriately $(87.11 \%, 81.56 \%$ and $85.63 \%$, respectively) (Table 5).

Around two thirds of the prescribers agreed or strongly agreed that they have easy access to the required guidelines on managing infections $(62.0 \%)$, and around half agreed or strongly agreed that they have easy access to materials that advise on prudent antibiotic use and antibiotic resistance (46.1\%). Moreover, $67.3 \%$ agreed or strongly agreed they had a good opportunity to provide such advice (Table 5). Nevertheless, $42.1 \%$ of prescribers would advise on prudent use of antibiotics for infections more than once a day or a week (Table 6). 
Table 5. Perceived knowledge, opportunity and motivation to prescribe antibiotics.

\begin{tabular}{|c|c|c|c|c|c|c|c|}
\hline Item & SA & A & $\mathbf{D}$ & SD & N/A & $\mathbf{U}$ & IDU \\
\hline \multicolumn{8}{|c|}{$\begin{array}{l}\text { One Health: environmental and animal health factors that are important in contributing to antibiotic resistance in bacteria } \\
\text { from humans }\end{array}$} \\
\hline $\begin{array}{l}\text { Excessive use of antibiotics in livestock and food } \\
\text { production is important in contributing to antibiotic } \\
\text { resistance in bacteria from humans }\end{array}$ & $\begin{array}{l}59 \\
9.6 \%\end{array}$ & $\begin{array}{l}308 \\
50.2 \%\end{array}$ & $\begin{array}{l}37 \\
6.0 \%\end{array}$ & $\begin{array}{l}8 \\
1.3 \%\end{array}$ & - & $\begin{array}{l}169 \\
27.6 \%\end{array}$ & $\begin{array}{l}32 \\
5.2 \%\end{array}$ \\
\hline $\begin{array}{l}\text { Environmental factors such as wastewater in the } \\
\text { environment are important in contributing to antibiotic } \\
\text { resistance in bacteria from humans }\end{array}$ & $\begin{array}{l}14 \\
2.3 \%\end{array}$ & $\begin{array}{l}180 \\
29.4 \%\end{array}$ & $\begin{array}{l}76 \\
12.4 \%\end{array}$ & $\begin{array}{l}8 \\
1.3 \%\end{array}$ & - & $\begin{array}{l}251 \\
40.9 \%\end{array}$ & $\begin{array}{l}84 \\
13.7 \%\end{array}$ \\
\hline \multicolumn{8}{|l|}{ Perceived knowledge } \\
\hline I know what antibiotic resistance is & $\begin{array}{l}192 \\
31.3 \%\end{array}$ & $\begin{array}{l}342 \\
55.8 \%\end{array}$ & $\begin{array}{l}15 \\
2.4 \%\end{array}$ & $\begin{array}{l}12 \\
2.0 \%\end{array}$ & $\begin{array}{l}22 \\
3.9 \%\end{array}$ & $\begin{array}{l}8 \\
1.3 \%\end{array}$ & $\begin{array}{l}22 \\
3.6 \%\end{array}$ \\
\hline $\begin{array}{l}\text { I know what information to give to individuals about } \\
\text { prudent use of antibiotics and antibiotic resistance }\end{array}$ & $\begin{array}{l}110 \\
17.9 \%\end{array}$ & $\begin{array}{l}390 \\
63.6 \%\end{array}$ & $\begin{array}{l}25 \\
4.1 \%\end{array}$ & 9 & $\begin{array}{l}9 \\
1.5 \%\end{array}$ & $\begin{array}{l}67 \\
10.9 \%\end{array}$ & $\begin{array}{l}3 \\
0.5 \%\end{array}$ \\
\hline $\begin{array}{l}\text { I have sufficient knowledge about how to use antibiotics } \\
\text { appropriately for my current practice }\end{array}$ & $\begin{array}{l}134 \\
21.9 \%\end{array}$ & $\begin{array}{l}391 \\
63.8 \%\end{array}$ & $\begin{array}{l}25 \\
4.1 \%\end{array}$ & $\begin{array}{l}8 \\
1.3 \%\end{array}$ & $\begin{array}{l}3 \\
0.5 \%\end{array}$ & $\begin{array}{l}51 \\
8.3 \%\end{array}$ & $\begin{array}{l}1 \\
0.2 \%\end{array}$ \\
\hline \multicolumn{8}{|l|}{ Opportunity } \\
\hline $\begin{array}{l}\text { I have easy access to guidelines I need on managing } \\
\text { infections }\end{array}$ & $\begin{array}{l}75 \\
12.2 \%\end{array}$ & $\begin{array}{l}305 \\
49.8 \%\end{array}$ & $\begin{array}{l}100 \\
16.3 \%\end{array}$ & $\begin{array}{l}19 \\
3.1 \%\end{array}$ & $\begin{array}{l}6 \\
1.0 \%\end{array}$ & $\begin{array}{l}103 \\
17.0 \%\end{array}$ & $\begin{array}{l}5 \\
0.8 \%\end{array}$ \\
\hline $\begin{array}{l}\text { I have easy access to the materials I need to give advice on } \\
\text { prudent antibiotic use and antibiotic resistance }\end{array}$ & $\begin{array}{l}37 \\
6.0 \%\end{array}$ & $\begin{array}{l}246 \\
40.1 \%\end{array}$ & $\begin{array}{l}174 \\
28.4 \%\end{array}$ & $\begin{array}{l}28 \\
4.6 \%\end{array}$ & $\begin{array}{l}19 \\
3.1 \%\end{array}$ & $\begin{array}{l}106 \\
17.3 \%\end{array}$ & $\begin{array}{l}3 \\
0.5 \%\end{array}$ \\
\hline $\begin{array}{l}\text { I have good opportunities to provide advice on prudent } \\
\text { antibiotic use to individuals }\end{array}$ & $\begin{array}{l}61 \\
10.0 \%\end{array}$ & $\begin{array}{l}351 \\
57.3 \%\end{array}$ & $\begin{array}{l}79 \\
12.9 \%\end{array}$ & $\begin{array}{l}13 \\
2.1 \%\end{array}$ & $\begin{array}{l}15 \\
2.4 \%\end{array}$ & $\begin{array}{l}92 \\
15.0 \%\end{array}$ & $\begin{array}{l}2 \\
0.3 \%\end{array}$ \\
\hline \multicolumn{8}{|l|}{ Motivation to initiate antibiotic prescriptions } \\
\hline $\begin{array}{l}\text { I know there is a connection between my prescribing of } \\
\text { antibiotics and emergence and spread of antibiotic } \\
\text { resistant bacteria }\end{array}$ & $\begin{array}{l}122 \\
19.9 \%\end{array}$ & $\begin{array}{l}294 \\
48.0 \%\end{array}$ & $\begin{array}{l}58 \\
9.5 \%\end{array}$ & $\begin{array}{l}24 \\
3.9 \%\end{array}$ & $\begin{array}{l}22 \\
3.6 \%\end{array}$ & $\begin{array}{l}79 \\
12.9 \%\end{array}$ & $\begin{array}{l}14 \\
2.3 \%\end{array}$ \\
\hline I am confident making antibiotic prescribing decisions & $\begin{array}{l}71 \\
11.6 \%\end{array}$ & $\begin{array}{l}391 \\
63.8 \%\end{array}$ & $\begin{array}{l}40 \\
6.5 \%\end{array}$ & $\begin{array}{l}9 \\
1.5 \%\end{array}$ & - & $\begin{array}{l}90 \\
14.7 \%\end{array}$ & $\begin{array}{l}12 \\
2.0 \%\end{array}$ \\
\hline $\begin{array}{l}\text { I have confidence in the antibiotic guidelines available } \\
\text { to me }\end{array}$ & $\begin{array}{l}68 \\
11.1 \%\end{array}$ & $\begin{array}{l}398 \\
64.9 \%\end{array}$ & $\begin{array}{l}53 \\
8.6 \%\end{array}$ & $\begin{array}{l}4 \\
0.7 \%\end{array}$ & - & $\begin{array}{l}82 \\
13.4 \%\end{array}$ & $\begin{array}{l}8 \\
1.3 \%\end{array}$ \\
\hline I have a key role in helping control antibiotic resistance & $\begin{array}{l}74 \\
12.1 \%\end{array}$ & $\begin{array}{l}354 \\
57.7 \%\end{array}$ & $\begin{array}{l}50 \\
8.2 \%\end{array}$ & $\begin{array}{l}3 \\
0.5 \%\end{array}$ & - & $\begin{array}{l}127 \\
20.7 \%\end{array}$ & $\begin{array}{l}5 \\
0.8 \%\end{array}$ \\
\hline I consider antibiotic resistance when treating a patient & $\begin{array}{l}116 \\
18.9 \%\end{array}$ & $\begin{array}{l}409 \\
66.7 \%\end{array}$ & $\begin{array}{l}21 \\
3.4 \%\end{array}$ & $\begin{array}{l}4 \\
0.7 \%\end{array}$ & - & $\begin{array}{l}59 \\
9.6 \%\end{array}$ & $\begin{array}{l}4 \\
0.7 \%\end{array}$ \\
\hline $\begin{array}{l}\text { I feel supported to not prescribe antibiotics when they are } \\
\text { not necessary }\end{array}$ & $\begin{array}{l}130 \\
21.2 \%\end{array}$ & $\begin{array}{l}276 \\
45.0 \%\end{array}$ & $\begin{array}{l}120 \\
19.6 \%\end{array}$ & $\begin{array}{l}37 \\
6.0 \%\end{array}$ & - & $\begin{array}{l}44 \\
7.2 \%\end{array}$ & $\begin{array}{l}6 \\
1.0 \%\end{array}$ \\
\hline
\end{tabular}

Abbreviations: SA: strongly agree; A: agree; D: disagree; SD: strongly disagree; N/A: not applicable; U: undecided; IDU: I do not understand.

The majority of prescribers (85.6\%) agreed or strongly agreed that they would consider antibiotic resistance when treating a patient. Around $75 \%$ of prescribers were confident in making prescribing decisions and confident about the available antibiotics guidelines on managing infections (Table 5). In addition, two thirds of prescribers agreed or strongly agreed that there is a connection between their prescription and antibiotic resistance, that they had a key role in helping control antibiotic resistance and that they felt supported not to prescribe antibiotics when they are not necessary. Several strategies were employed to prescribe antibiotics prudently including delayed prescribing $(n=210,34.3 \%)$, patient education $(n=422,68.8 \%)$ and new patient consultation $(n=90,14.7 \%)$. However, 73 $(11.9 \%)$ prescribers would not follow any strategy. 
Table 6. The frequency with which prescribers provided antibiotics or resources related to prudent use of antibiotics, behavior on drivers for initiating prescriptions and antibiotic prescribing behaviors.

\begin{tabular}{|c|c|c|c|c|c|c|c|c|}
\hline Item & $>Q D$ & $>Q W$ & NVR & $\mathbf{R}$ & QD & QW & N/A & IDR \\
\hline \multicolumn{9}{|c|}{ Opportunity to provide antibiotics or resources related to prudent use of antibiotics } \\
\hline \multirow{2}{*}{$\begin{array}{l}\text { How often did you prescribe antibiotics during the last } \\
\text { one week? }\end{array}$} & 169 & 107 & & 53 & & & & 12 \\
\hline & $27.6 \%$ & $17.5 \%$ & $12.4 \%$ & $8.7 \%$ & $14.0 \%$ & $14.0 \%$ & & $2.0 \%$ \\
\hline \multirow{2}{*}{$\begin{array}{l}\text { How often did you give out resources (e.g., leaflets or } \\
\text { pamphlets) on prudent antibiotic use or management of } \\
\text { infections to individuals during the last one week? }\end{array}$} & 37 & 74 & 230 & 159 & 14 & 52 & 47 & 0 \\
\hline & $6.0 \%$ & $12.1 \%$ & $37.5 \%$ & $25.9 \%$ & $2.3 \%$ & $8.5 \%$ & $7.7 \%$ & $0.0 \%$ \\
\hline \multirow{2}{*}{$\begin{array}{l}\text { How often did you give out advice related to prudent } \\
\text { antibiotic use or management of infections to an } \\
\text { individual during the last one week }\end{array}$} & 143 & 115 & 69 & 86 & 39 & 103 & 19 & 39 \\
\hline & $23.3 \%$ & $18.8 \%$ & $11.3 \%$ & $14.0 \%$ & $6.4 \%$ & $16.8 \%$ & $3.1 \%$ & $6.4 \%$ \\
\hline \multicolumn{9}{|l|}{ Behavior on drivers for initiating prescriptions } \\
\hline \multirow{2}{*}{$\begin{array}{l}\text { How often would you have preferred not to prescribe an } \\
\text { antibiotic but were not able to during the last one week? }\end{array}$} & 86 & 88 & 124 & 132 & 33 & 98 & 0 & 52 \\
\hline & $14.0 \%$ & $14.4 \%$ & $20.2 \%$ & $21.5 \%$ & $5.4 \%$ & $16.0 \%$ & $0.0 \%$ & $8.5 \%$ \\
\hline \multirow{2}{*}{$\begin{array}{l}\text { How often did the fear of patient deterioration or fear of } \\
\text { complications lead you to prescribe antibiotics during the } \\
\text { last one week? }\end{array}$} & 53 & 67 & 132 & 157 & 34 & 118 & 0 & 52 \\
\hline & $8.7 \%$ & $10.9 \%$ & $21.5 \%$ & $25.6 \%$ & $5.6 \%$ & $19.3 \%$ & $0.0 \%$ & $8.5 \%$ \\
\hline \multirow{2}{*}{$\begin{array}{l}\text { How often did you prescribe antibiotics because it took } \\
\text { less time than to explain the reason why they are not } \\
\text { indicated during the last one week? }\end{array}$} & 47 & 42 & 219 & 154 & 35 & 63 & 0 & 53 \\
\hline & $7.7 \%$ & $6.9 \%$ & $35.7 \%$ & $25.1 \%$ & $5.7 \%$ & $10.3 \%$ & $0.0 \%$ & $8.7 \%$ \\
\hline \multirow{2}{*}{$\begin{array}{l}\text { How often did you prescribe antibiotics in situations in } \\
\text { which it is impossible for you to conduct a follow-up of } \\
\text { the patient during the last one week }\end{array}$} & 27 & 49 & 181 & 156 & 19 & 98 & 0 & 83 \\
\hline & $4.4 \%$ & $8.0 \%$ & $29.5 \%$ & $25.5 \%$ & $3.1 \%$ & $16.0 \%$ & $0.0 \%$ & $13.5 \%$ \\
\hline \multirow{2}{*}{$\begin{array}{l}\text { How often did you prescribe an antibiotic to maintain the } \\
\text { relationship with the patient during the last one week? }\end{array}$} & 28 & 30 & 296 & 130 & 22 & 63 & 0 & 44 \\
\hline & $4.6 \%$ & $4.9 \%$ & $48.3 \%$ & $21.2 \%$ & $3.6 \%$ & $10.3 \%$ & $0.0 \%$ & $7.2 \%$ \\
\hline \multirow{2}{*}{$\begin{array}{l}\text { How often did you prescribe an antibiotic because you } \\
\text { were uncertain about the diagnosis of infection during the } \\
\text { last one week }\end{array}$} & 24 & 50 & 228 & 162 & 20 & 79 & 0 & 50 \\
\hline & $3.9 \%$ & $8.2 \%$ & $37.2 \%$ & $26.4 \%$ & $3.7 \%$ & $12.9 \%$ & $0.0 \%$ & $8.7 \%$ \\
\hline \multicolumn{9}{|l|}{ Antibiotic prescribing behavior } \\
\hline \multirow{2}{*}{$\begin{array}{l}\text { How often did you stop an antibiotic prescription earlier } \\
\text { than the prescribed course length during the last } \\
\text { one week? }\end{array}$} & 15 & 28 & 274 & 138 & 15 & 61 & 0 & 82 \\
\hline & $2.5 \%$ & $4.6 \%$ & $44.7 \%$ & $22.5 \%$ & $2.5 \%$ & $10.0 \%$ & $0.0 \%$ & $13.4 \%$ \\
\hline \multirow{2}{*}{$\begin{array}{l}\text { How often did you prescribe a shorter course of treatment } \\
\text { as compared to available guidelines during the last } \\
\text { one week? }\end{array}$} & 20 & 33 & 254 & 148 & 13 & 57 & 0 & 88 \\
\hline & $3.3 \%$ & $5.4 \%$ & $41.4 \%$ & $24.1 \%$ & $2.1 \%$ & $9.3 \%$ & $0.0 \%$ & $14.4^{\circ}$ \\
\hline \multirow{2}{*}{$\begin{array}{l}\text { How often did you discontinue early (within three days } \\
\text { after initiation) a treatment because bacterial infection } \\
\text { was not likely after all during the last one week }\end{array}$} & 20 & 33 & 249 & 159 & 15 & 54 & 0 & 83 \\
\hline & $3.3 \%$ & $5.4 \%$ & $40.6 \%$ & $25.9 \%$ & $2.5 \%$ & $8.8 \%$ & $0.0 \%$ & $13.5 \%$ \\
\hline
\end{tabular}

Abbreviations: QD: once a day; QW: once a week; NVR: never; R: rarely; N/A: not applicable; IDR: I do not remember.

Most of the respondents would prescribe antibiotics daily ( $n=262,42.7 \%)$ or weekly $(n=209,34.1)$, with $10.8 \%(n=66)$ monthly, $6.0 \%(n=37)$ quarterly and $6.4 \%(n=39)$ yearly. Although $27.6 \%$ of prescribers did prescribe antibiotics more than once a day, more than $50 \%$ would never or rarely give out resources on prudent use of antibiotics for infections (Table 6). Reasons for not providing resources included the following: "Patient does not require information" $(n=73,11.9 \%)$, "Patient uninterested in information" $(n=244$, $39.8 \% \%)$, "Insufficient time" ( $n=183,29.9 \%)$, "Difficulty getting patient to understand diagnosis" $(n=139,22.7 \%)$, "Language barriers" $(n=17,2.8 \%)$, "No resources available" ( $n=162,12.0 \%)$, "I was not sure what advice to provide" ( $n=28,4.6 \%)$ and "I was able to give out advice or resources as needed" ( $n=185,30.2 \%)$.

Regarding behaviors on drivers to initiate prescriptions, $47.2 \%$ of respondents would rarely or never prescribe antibiotics because of fear of patient deterioration or fear of complications. On the other hand, $28.4 \%$ of respondents have prescribed antibiotics when 
they have preferred not to do so more than once a day or more than once a week, and $10.3 \%$ of respondents had prescribed antibiotics once a week because it took less time than to explain the reason why they are not indicated during the last week. Two thirds of respondents claimed that they would never or rarely prescribe antibiotics in situations in which it is impossible to conduct a follow-up of the patient or maintain a relationship with the patient, or due to being uncertain about the diagnosis of infection. Around $40 \%$ of respondents would never stop an antibiotic prescription earlier than the prescribed course length, prescribe a shorter course of treatment compared to available guidelines or discontinue early treatment because a bacterial infection was not likely after all.

Concerning the One Health question, most of the respondents were unsure if it is legal to use antibiotics to stimulate growth in farm animals, with only $14.2 \%$ answering correctly (Table 2). Furthermore, 59.8\% of participants agreed or strongly agreed that excessive use of antibiotics in livestock and food production is important in contributing to antibiotic resistance in bacteria from humans. In comparison, $40.9 \%(n=251)$ of respondents could not decide whether environmental factors contribute to antibiotic resistance (Table 5). When asked about the level of when it is most effective to tackle resistance to antibiotics, only $55.3 \%(n=339)$ answered that action at all levels is required. Others responded at the individual level (prescribers) $(n=230,37.5 \%)$, regional/national level $(n=128,20.9 \%)$, global level $(n=120,19.6 \%)$ and environmental or animal health level $(n=31,5.1 \%)$, and $6.0 \%(n=37)$ did not know the answer.

\section{Discussion}

To our knowledge, this is the first study in the Middle East area to assess the knowledge, attitudes and behaviors about antibiotic use and antibiotic resistance among physicians and dentists using the ECDC's validated instrument [22,23]. Antimicrobial resistance is an emerging health threat worldwide, driving a real necessity for rational antibiotic use and following guidelines in treating patients to preserve antimicrobial activity [24,25]. In our study, physicians' knowledge regarding antibiotic resistance was found to be higher compared to dentists and was significantly linked to more years in practice. Most responders in the studied group believed that they have adequate knowledge about antimicrobial resistance and the ability to give the right prescription and appropriate medical advice with respect to antibiotics. Although only fifty percent of the prescribers reported that they have access to the most recent guidelines, the majority still believe that they can use antibiotics prudently.

A study conducted by Wushouer and colleagues in China reported that the higher the knowledge of the practitioners, the lower the rate of antibiotic prescribing [26]. This was also reported in a German study that assessed the effect of knowledge about antibiotic resistance on the prescribing pattern among practitioners; awareness about antimicrobial resistance highly influenced the practitioners' pattern in prescribing antibiotics to their patients, and this was confirmed in additional studies in Iran and Croatia [27-29]. Conversely, two studies in Cambodia and Nigeria found that physicians were alert about the challenge related to the misuse of antibiotics, but this did not influence their practice in managing antibiotic prescribing [30,31]. Understanding the factors associated with overprescribing of antibiotics including prescribers' knowledge is crucial to find strategies to overcome this challenge [32-34]. In our study, $45.7 \%$ of the participants were specialists with higher knowledge scores when compared to generalists. This may contribute to the proper use of antibiotics as per many studies, particularly as general physicians tend to prescribe antibiotics more commonly compared to specialists $[29,35,36]$.

Additionally, we found that most of the participating physicians and dentists achieved a high score in questions related to effectiveness, inappropriate use and adverse effects but scored less well in questions addressing antimicrobial resistance. This is similar to a study conducted in the United States in which the authors compared the prescribing behavior of those prescribing high rates versus those prescribing low rates of antibiotics [37]. Higher prescribing rates were found to be associated with patient satisfaction and needs rather 
than antibiotic side effects or evidence-based medicine [37]. Although the requirement for antibiotics is less common in dentistry, there are still many more antibiotic prescriptions which may be attributed to the level of knowledge about antibiotics and antimicrobial resistance among dentists compared to physicians, as observed in our study [38,39]. Half of our participants believed that there is a lack of open access resources to find recent guidelines and information that support their prudent antibiotics use, while a study in Germany found that only $7 \%$ of physicians believed this to be true [27]. A Swedish study found that increasing awareness and continuous education for healthcare providers are fundamental to manage antimicrobial resistance [40]. Thus, as with many other countries, provision of continuing education for healthcare providers is required nationally [1,40-42].

Multiple factors were found to contribute to antibiotic prescribing decisions including psychological and socioeconomical factors, in addition to clinical aspects [37,43-45]. Machowska and colleagues reported that practitioners' knowledge and attitudes toward antibiotics use, lack of training on antibiotic prescribing during education and pharmaceutical promotional activities were among the most important factors, as well as the physician-patient relationship [44]. Patient satisfaction is another factor that may contribute to antibiotic prescribing decisions, as shown in an Iranian study in which $69 \%$ of the patients would be concerned about their medical condition if an antibiotic was not prescribed [28].

Despite the findings that both physicians and dentists knew about strategies to promote prudent antibiotic use, these were not implemented effectively. It is known that delaying antibiotic prescribing can control inappropriate antibiotic use without affecting the health outcomes for patients [46,47]; however, many practitioners in this study did not use this strategy. According to De la Poza Abad and colleagues, $46 \%$ of physicians in Spanish primary care settings were found to use this strategy, especially when treating respiratory tract infections [48]. However, our findings indicate that higher percentages of prescribers have used this strategy of delayed prescribing (34.3\%) compared to those reported in Germany (29.4\%) [27].

The majority of the prescribers indicated that they tend to prescribe antibiotics on a daily basis, similar to high rates reported in other studies $[32,47,49]$. While the tendency to prescribe antibiotics was high, the practitioners believed that they prescribe antibiotics mostly when indicated. This has not always been the case in other studies, for example, $54 \%$ of Cambodian physicians believed that most antibiotic prescriptions were inappropriate [30]. In a nationwide retrospective study for rational use in dentistry, $96.6 \%$ of prescriptions were prescribed for irrational indications including dental caries [50]. Furthermore, a qualitative study showed that antibiotics were prescribed due to the fear of deterioration of a patient's health status [51]. Using antibiotics in poultry is one of the factors that affects antibiotic resistance worldwide [52-54]. Lower proportions of participants in our study were aware of the risk of antibiotic resistance related to use in agriculture and food production compared to that reported by the ECDC survey [23].

This study has some limitations. First, this study used an online survey that may introduce selection bias. However, this is less likely to affect our results, particularly as the survey was sent to physicians and dentists (literate population) who are increasingly using the internet and smartphones in their practice [55-57]. In addition, our sample included more prescribers of a younger age. This study would benefit from more involvement of prescribers from other age groups. Evidence from the literature suggests that age is less likely to influence the use of smartphones among physicians [58,59].

In conclusion, the results of this study indicate that antibiotic resistance should direct our plans to a more robust system to educate our practitioners and update them about local and global antibiotic use status and antimicrobial resistance. The findings are of importance to inform antimicrobial stewardship with relevant interventions aiming at changing prescribers' behaviors and improving antibiotic prescribing practices. 


\section{Materials and Methods}

\subsection{Study Design and Setting}

A cross-sectional study survey of Jordanian physicians and dentists was conducted using an online questionnaire. This survey was conducted using the European Centre for Disease Prevention and Control's (ECDC) validated instrument [22,23].

Physicians and dentists from all sectors were eligible to participate in the study. A webbased survey software (Google Forms) was used to collect data, applying the "required" and "Limit to one response" validation options. Physicians and dentists were recruited through a variety of means, including direct mail, online recruiting, online professional conferences and social media. Participants received an invitation leading them to a Google Forms-based online survey with more comprehensive details about the study. Participants were provided with a brief description of the study and informed that their participation was voluntary and that their responses would be anonymized and treated as confidential.

\subsection{Survey Instrument}

A $10 \mathrm{~min}$ online questionnaire was adapted from the questionnaire developed and tested by the European Centre for Disease Prevention and Control (ECDC) [22,23] (Questionnaire S1—Supplementary Material). The survey began with questions designed to collect details about sociodemographic variables. The second section asked 8 questions to test respondents' actual knowledge using true or false questions. Four questions were to assess knowledge on effective use, unnecessary use or associated side effects of antibiotics, three questions were on the spread of antibiotic resistance and one question was to assess knowledge on antibiotic resistance in the context of the animal sector. Scores of this scale ranged between 0 and 8, with one point given for each correct answer.

Section three consisted of a 5-point Likert scale (strongly agree to strongly disagree), in addition to not applicable/I do not understand the question. A level of agreement was obtained on 14 statements, including two statements on antibiotic resistance in the context of food and environmental factors, three statements that assessed perceived knowledge, three statements that assessed opportunities that may affect prudent prescribing and management of infections, three statements that assessed available opportunities to enact positive behaviors for preventing and controlling AMR and six statements that were on prescribers' motivations to initiate antibiotic prescriptions and antibiotic prescribing decisions, support and accessibility to guidelines.

The fourth section included 12 questions on the frequency with which prescribers provided antibiotics or resources related to the prudent use of antibiotics (3 questions), behavior on drivers for initiating prescriptions (6 questions) and antibiotic prescribing behaviors (3 questions). Questions on the frequency were asked concerning the last week, with options that included more than once a day, more than once a week, once a day, never and rarely, in addition to "not applicable" and "I do not remember" options. The frequency of antibiotic prescribing, in general, was also obtained from respondents. Prescribers were also asked about why they were unable to provide any resources to their patients, strategies employed to prescribe antibiotics prudently and the level of implementation they think would be most effective to tackle resistance to antibiotics.

The questionnaire was administered in both Arabic and English languages for better interpretation. Prescribers had the option to choose any of the two languages. An initial online pretest of the questionnaire was performed with 10 physicians and dentists. Each participant was interviewed to determine whether the questions were correctly interpreted and if the answer options given were adequate. Based on the pretest interviews, minor adjustments were made to the questionnaire. The pilot interview data were not included in the final sample.

\subsection{Statistical Analysis}

The sample size was determined, using Raosoft sample size calculator (http:/ / www. raosoft.com/samplesize.html), based on a margin of error of $5 \%$, confidence level of $95 \%$, 
population size of 36,000 (total of registered physicians and dentists in Jordan) and a response distribution of $50 \%$. The calculated sample size was 381. Google Forms was connected to a Google spreadsheet for further analysis and data organization. The IBM SPSS (Statistical Package for the Social Sciences, Armonk, NY, USA) version 24.0 software was used to analyze the collected data. The percentages, frequencies, means and standard deviations were used to display the results. An analysis of variance (ANOVA) test or t-test was used to examine the effect of demographic characteristics on respondents' knowledge scores. The chi-square test or Fisher's exact test was used to examine differences among respondents with a full knowledge score. Finally, a multivariable linear regression model was conducted to assess predictors of knowledge, adjusting for confounding variables. The significance of all results was determined using a $p$-value of less than 0.05 .

Supplementary Materials: The following are available online at https:/ / www.mdpi.com/article/10 .3390 /antibiotics10070858/s1, Questionnaire S1. Survey of physicians and dentists knowledge and attitudes about antibiotics and antibiotic resistance.

Author Contributions: Conceptualization, all authors; methodology, R.A.K., S.I.A.-A., M.A.A., Y.S.K., B.R.C. and M.A.A.; software, R.A.K. and M.A.; validation, S.M.M., M.K. and A.-R.M.K.; formal analysis, R.A.K. and M.A.; resources, S.I.A.-A., B.R.C. and M.A.A.; writing-original draft preparation, R.A.K.; writing-review and editing, S.I.A.-A., B.R.C., M.A.A., O.B.A.-B., Y.S.K. and all authors; supervision, S.I.A.-A., and M.A.A.; project administration, O.A.-A., and O.B.A.-B. All authors have read and agreed to the published version of the manuscript.

Funding: This research was funded by the Jordan University of Science and Technology, grant number 195/2021.

Institutional Review Board Statement: This study was conducted according to the guidelines of the Declaration of Helsinki and approved by the Institutional Review Board of the Jordan University of Science and Technology (IRB, Reference: 10/140/2021).

Informed Consent Statement: Participants received an invitation leading them to a Google Formsbased online survey.

Data Availability Statement: Data are available on reasonable request and in line with permission approval processes from the Jordan University of Science and Technology.

Acknowledgments: We would like to thank the European Centre for Disease Prevention and Control (ECDC) for sharing its questionnaire with us for the purposes of conducting this study.

Conflicts of Interest: The authors declare no conflict of interest.

\section{References}

1. Aldeyab, M.; López-Lozano, J.M.; Gould, I.M. Global Antibiotics Use and Resistance. In Babar ZUD; Global Pharmaceutical Policy, Ed.; Palgrave Macmillan: Singapore, 2020. [CrossRef]

2. O'Neill, J. Antimicrobial Resistance: Tackling a Crisis for the Health and Wealth of Nations; The Review on Antimicrobial Resistance: London, UK, 2014.

3. Cosgrove, S.E. The relationship between antimicrobial resistance and patient outcomes: Mortality, length of hospital stay, and health care costs. Clin. Infect. Dis. 2006, 42, S82-S89. [CrossRef] [PubMed]

4. World Bank. Drug-Resistant Infections: A Threat to Our Economic Future; HNP/Agriculture Global Antimicrobial Resistance Initiative; World Bank Group: Washington, DC, USA, 2017.

5. Tomson, G.; Vlad, I. The need to look at antibiotic resistance from a health systems perspective. Upsala J. Med. Sci. 2014, 119, 117-124. [CrossRef] [PubMed]

6. Hayajneh, W.A.; Al-Azzam, S.; Yusef, D.; Lattyak, W.J.; Lattyak, E.A.; Gould, I.; López-Lozano, J.M.; Conway, B.R.; ConlonBingham, G.; Aldeyab, M.A. Identification of thresholds in relationships between specific antibiotic use and carbapenem-resistant Acinetobacter baumannii (CRAb) incidence rates in hospitalized patients in Jordan. J. Antimicrob. Chemother. 2021, 76, 524-530. [CrossRef] [PubMed]

7. Yusef, D.; Hayajneh, W.A.; Bani Issa, A.; Haddad, R.; Al-Azzam, S.; Lattyak, E.A.; Lattyak, W.J.; Gould, I.; Conway, B.R.; Bond, S.; et al. Impact of an antimicrobial stewardship programme on reducing broad-spectrum antibiotic use and its effect on carbapenem-resistant Acinetobacter baumannii (CRAb) in hospitals in Jordan. J. Antimicrob. Chemother. 2021, 76, 516-523. [CrossRef] 
8. Conlon-Bingham, G.M.; Aldeyab, M.; Scott, M.; Kearney, M.P.; Farren, D.; Gilmore, F.; McElnay, J. Effects of antibiotic cycling policy on incidence of healthcare-associated MRSA and clostridioides difficile infection in secondary healthcare settings. Emerg. Infect. Dis. 2019, 25, 52-62. [CrossRef]

9. Jirjees, F.J.; Al-Obaidi, H.J.; Sartaj, M.; ConlonBingham, G.; Farren, D.; Scott, M.G.; Gould, I.M.; López-Lozano, J.M.; Aldeyab, M.A. Antibiotic use and resistance in hospitals: Time-series analysis strategy for determining and prioritising interventions. Hosp. Pharm. Eur. 2020, 13-19. Available online: https://hospitalpharmacyeurope.com/news/reviews-research/antibiotic-use-andresistance-in-hospitals-time-series-analysis-strategy-for-determining-and-prioritising-interventions/ (accessed on 27 May 2021).

10. Davey, P.; Marwick, C.A.; Scott, C.L.; Charani, E.; Mcneil, K.; Brown, E.; Gould, I.M.; Ramsay, C.R.; Michie, S. Interventions to improve antibiotic prescribing practices for hospital inpatients. Cochrane Database Syst. Rev. 2017, 2, CD003543. [CrossRef]

11. Plachouras, D.; Kärki, T.; Hansen, S.; Hopkins, S.; Lyytikäinen, O.; Moro, M.L.; Reilly, J.; Zarb, P.; Zingg, W.; Kinross, P.; et al. Antimicrobial use in european acute care hospitals: Results from the second point prevalence survey (PPS) of healthcare-associated infections and antimicrobial use, 2016 to 2017. Eurosurveillance 2018, 23, 1. [CrossRef]

12. Schuts, E.C.; Hulscher, M.E.J.L.; Mouton, J.W.; Verduin, C.M.; Stuart, J.W.T.C.; Overdiek, H.W.P.M.; van der Linden, P.D.; Natsch, S.; Hertogh, C.M.P.M.; Wolfs, T.F.W.; et al. Current evidence on hospital antimicrobial stewardship objectives: A systematic review and meta-analysis. Lancet Infect. Dis. 2016, 16, 847-856. [CrossRef]

13. Elhajji, F.D.; Al-Taani, G.M.; Anani, L.; Al-Masri, S.; Abdalaziz, H.; Qabba'H, S.H.; Al Bawab, A.Q.; Scott, M.; Farren, D.; Gilmore, F.; et al. Comparative point prevalence survey of antimicrobial consumption between a hospital in Northern Ireland and a hospital in Jordan 11 Medical and Health Sciences 1103 Clinical Sciences. BMC Health Serv. Res. 2018, 18, 849. [CrossRef]

14. Cormican, M.; Vellinga, A. Existing classes of antibiotics are probably the best we will ever have. BMJ 2012, 344, e3369. [CrossRef]

15. Courvalin, P. Why is antibiotic resistance a deadly emerging disease? Clin. Microbiol. Infect. 2016, 22, 405-407. [CrossRef]

16. Resolution WHA 68-7 Global Action Plan on Antimicrobial Resistance. Microbe Mag. 2015, 10, 354-355. [CrossRef]

17. Teixeira Rodrigues, A.; Roque, F.; Falcão, A.; Figueiras, A.; Herdeiro, M.T. Understanding physician antibiotic prescribing behaviour: A systematic review of qualitative studies. Int. J. Antimicrob. Agents 2013, 41, 203-212. [CrossRef]

18. Charani, E.; Edwards, R.; Sevdalis, N.; Alexandrou, B.; Sibley, E.; Mullett, D.; Franklin, B.D.; Holmes, A. Behavior change strategies to influence antimicrobial prescribing in acute care: A systematic review. Clin. Infect. Dis. 2011, 53, 651-662. [CrossRef]

19. Paget, J.; Lescure, D.; Versporten, A.; Goossens, H.; Schellevis, F.; van Dijk, L. ANTIMICROBIAL RESISTANCE and Causes of Non-Prudent Use of Antibiotics in Human Medicine in the EU; European Commisson: Brussels, Belgium, 2017.

20. Pinder, R.; Sallis, A.; Berry, D.; Chadborn, T. Behaviour Change and Antibiotic Prescribing in Healthcare Settings Literature Review and Behavioural Analysis about Public Health England about the Department of Health; Department of Health \& Public Health England: London, UK, 2015. Available online: https:/ / assets.publishing.service.gov.uk/government/uploads/system/uploads/ attachment_data/file/774129/Behaviour_Change_for_Antibiotic_Prescribing_-_FINAL.pdf (accessed on 27 May 2021).

21. Ministry of Health National Action Plan for Combating Antimicrobial Resistance in the Hashemite Kingdom of Jordan. 2018. Available online: https://www.moh.gov.jo/EchoBusV3.0/SystemAssets/communicable/AMR\%20plan.pdf (accessed on 1 July 2021).

22. Ashiru-Oredope, D.; Hopkins, S.; Vasandani, S.; Umoh, E.; Oloyede, O.; Nilsson, A.; Kinsman, J.; Elsert, L.; Monnet, D.L. Healthcare workers' knowledge, attitudes and behaviours with respect to antibiotics, antibiotic use and antibiotic resistance across 30 EU/EEA countries in 2019. Eurosurveillance 2021, 26, 1900633. [CrossRef]

23. European Centre for Disease Prevention and Control. Survey of Healthcare Workers' Knowledge, Attitudes and Behaviours on Antibiotics, Antibiotic Use and Antibiotic Resistance in the EU/EEA; ECDC: Solna Municipality, Sweden, 2019. Available online: https:/ / www.ecdc.europa.eu/sites/default/files/documents/survey-of-healthcare-workers-knowledge-attitudesbehaviours-on-antibiotics.pdf (accessed on 31 May 2021).

24. Hsia, Y.; Lee, B.R.; Versporten, A.; Yang, Y.; Bielicki, J.; Jackson, C.; Newland, J.; Goossens, H.; Magrini, N.; Sharland, M. Use of the WHO Access, Watch, and Reserve classification to define patterns of hospital antibiotic use (AWaRe): An analysis of paediatric survey data from 56 countries. Lancet Glob. Health 2019, 7, e861-e871. [CrossRef]

25. Obakiro, S.B.; Kiyimba, K.; Paasi, G.; Napyo, A.; Anthierens, S.; Waako, P.; Royen, P.V.; Iramiot, J.S.; Goossens, H.; Kostyanev, T. Prevalence of antibiotic-resistant bacteria among patients in two tertiary hospitals in Eastern Uganda. J. Glob. Antimicrob. Resist. 2021, 25, 82-86. [CrossRef]

26. Wushouer, H.; Wang, Z.; Tian, Y.; Zhou, Y.; Zhu, D.; Vuillermin, D.; Shi, L.; Guan, X. The impact of physicians' knowledge on outpatient antibiotic use: Evidence from China's county hospitals. Medicine 2020, 99, e18852. [CrossRef]

27. Salm, F.; Schneider, S.; Schmücker, K.; Petruschke, I.; Kramer, T.S.; Hanke, R.; Schröder, C.; Heintze, C.; Schwantes, U.; Gastmeier, P.; et al. Antibiotic prescribing behavior among general practitioners-A questionnaire-based study in Germany. BMC Infect. Dis. 2018, 18, 208. [CrossRef]

28. Vakili-Arki, H.; Aalaei, S.; Farrokhi, M.; Nabovati, E.; Saberi, M.R.; Eslami, S. A survey of perceptions, attitudes and practices regarding the antibiotic prescription among Iranian physicians. Expert Rev. Anti. Infect. Ther. 2019, 17, 741-748. [CrossRef]

29. Farkaš, M.; Glažar Ivče, D.; Stojanović, S.; Mavrinac, M.; Mićović, V.; Tambić Andrašević, A. Parental knowledge and awareness linked to antibiotic use and resistance: Comparison of urban and rural population in Croatia. Microb. Drug Resist. 2019, 25, 1430-1436. [CrossRef]

30. Om, C.; Vlieghe, E.; McLaughlin, J.C.; Daily, F.; McLaws, M.L. Antibiotic prescribing practices: A national survey of Cambodian physicians. Am. J. Infect. Control. 2016, 44, 1144-1148. [CrossRef] 
31. Chukwu, E.E.; Oladele, D.A.; Enwuru, C.A.; Gogwan, P.L.; Abuh, D.; Audu, R.A.; Ogunsola, F.T. Antimicrobial resistance awareness and antibiotic prescribing behavior among healthcare workers in Nigeria: A national survey. BMC Infect. Dis. 2021, 21, 22. [CrossRef]

32. Liu, C.; Liu, C.; Wang, D.; Deng, Z.; Tang, Y.; Zhang, X. Determinants of antibiotic prescribing behaviors of primary care physicians in Hubei of China: A structural equation model based on the theory of planned behavior. Antimicrob. Resist. Infect. Control. 2019, 8, 23. [CrossRef]

33. O'Brien, A.P.; Rawlins, M.D.; Ingram, P.R. Appropriateness and determinants of antibiotic prescribing in an Australian emergency department. EMA Emerg. Med. Australas. 2015, 27, 83-84. [CrossRef]

34. Rose, J.; Crosbie, M.; Stewart, A. A qualitative literature review exploring the drivers influencing antibiotic over-prescribing by GPs in primary care and recommendations to reduce unnecessary prescribing. Perspect. Public Health 2021, 141, 19-27. [CrossRef]

35. Leong, T.W.; Rahmah, S.; Ishak, S.; Ali, Z. Knowledge, attitude and practice of antibiotics prescribing among medical officers of public health care facilities in the state of Kedah, Malaysia. Med. J. Malays. 2015, 70, 307-311.

36. Turner, B.J.; Laine, C. Differences between generalists and specialists: Knowledge, realism, or primum non nocere? J. Gen. Intern. Med. 2001, 16, 422-424. [CrossRef] [PubMed]

37. Patel, A.; Pfoh, E.R.; Misra Hebert, A.D.; Chaitoff, A.; Shapiro, A.; Gupta, N.; Rothberg, M.B. Attitudes of High Versus Low Antibiotic Prescribers in the Management of Upper Respiratory Tract Infections: A Mixed Methods Study. J. Gen. Intern. Med. 2020, 35, 1182-1188. [CrossRef] [PubMed]

38. Oberoi, S.S.; Dhingra, C.; Sharma, G.; Sardana, D. Antibiotics in dental practice: How justified are we. Int. Dent. J. 2015, 65, 4-10. [CrossRef] [PubMed]

39. Stein, K.; Farmer, J.; Singhal, S.; Marra, F.; Sutherland, S.; Quiñonez, C. The use and misuse of antibiotics in dentistry: A scoping review. J. Am. Dent. Assoc. 2018, 149, 869-884. [CrossRef]

40. Mölstad, S.; Löfmark, S.; Carlin, K.; Erntell, M.; Aspevall, O.; Blad, L.; Hanberger, H.; Hedin, K.; Hellman, J.; Norman, C.; et al. Lessons learnt during 20 years of the swedish strategic programme against antibiotic resistance. Bull. World Health Organ. 2017, 95, 764-773. [CrossRef]

41. Zetts, R.M.; Stoesz, A.; Smith, B.A.; Hyun, D.Y. Outpatient antibiotic use and the need for increased antibiotic stewardship efforts. Pediatrics 2018, 141, e20174124. [CrossRef]

42. Kjærsgaard, M.; Leth, R.A.; Udupi, A.; Ank, N. Antibiotic stewardship based on education: Minor impact on knowledge, perception and attitude. Infect. Dis. 2019, 51, 753-763. [CrossRef]

43. King, L.M.; Fleming-Dutra, K.E.; Hicks, L.A. Advances in optimizing the prescription of antibiotics in outpatient settings. BMJ 2018, 363, k3047. [CrossRef]

44. Machowska, A.; Lundborg, C.S. Drivers of Irrational Use of Antibiotics in Europe. Int. J. Environ. Res. Public Health 2018, 16, 27. [CrossRef]

45. Van Der Zande, M.M.; Dembinsky, M.; Aresi, G.; Van Staa, T.P. General practitioners' accounts of negotiating antibiotic prescribing decisions with patients: A qualitative study on what influences antibiotic prescribing in low, medium and high prescribing practices. BMC Fam. Pract. 2019, 20, 172. [CrossRef]

46. Spurling, G.K.P.; Del Mar, C.B.; Dooley, L.; Foxlee, R.; Farley, R. Delayed antibiotic prescriptions for respiratory infections. Cochrane Database Syst. Rev. 2017, 2017. [CrossRef]

47. Morrell, L.; Buchanan, J.; Roope, L.S.J.; Pouwels, K.B.; Butler, C.C.; Hayhoe, B.; Moore, M.V.; Tonkin-Crine, S.; McLeod, M.; Robotham, J.V.; et al. Delayed antibiotic prescription by general practitioners in the UK: A stated-choice study. Antibiotics 2020, 9 , 608. [CrossRef]

48. De La Poza Abad, M.; Mas Dalmau, G.; Gich Saladich, I.; Martínez García, L.; Llor, C.; Alonso-Coello, P. Use of delayed antibiotic prescription in primary care: A cross-sectional study. BMC Fam. Pract. 2019, 20, 1-6. [CrossRef]

49. Del Mar, C.B.; Scott, A.M.; Glasziou, P.P.; Hoffmann, T.; van Driel, M.L.; Beller, E.; Phillips, S.M.; Dartnell, J. Reducing antibiotic prescribing in Australian general practice: Time for a national strategy. Med. J. Aust. 2017, 207, 401-406. [CrossRef] [PubMed]

50. Koyuncuoglu, C.Z.; Aydin, M.; Kirmizi, N.I.; Aydin, V.; Aksoy, M.; Isli, F.; Akici, A. Rational use of medicine in dentistry: Do dentists prescribe antibiotics in appropriate indications? Eur. J. Clin. Pharmacol. 2017, 73, 1027-1032. [CrossRef] [PubMed]

51. Kumar, S.; Little, P.; Britten, N. Why do general practitioners prescribe antibiotics for sore throat? Grounded theory interview study. Br. Med. J. 2003, 326, 138-141. [CrossRef]

52. Manyi-Loh, C.; Mamphweli, S.; Meyer, E.; Okoh, A. Antibiotic use in agriculture and its consequential resistance in environmental sources: Potential public health implications. Molecules 2018, 23, 795. [CrossRef] [PubMed]

53. Kimera, Z.I.; Frumence, G.; Mboera, L.E.G.; Rweyemamu, M.; Mshana, S.E.; Matee, M.I.N. Assessment of drivers of antimicrobial use and resistance in poultry and domestic pig farming in the Msimbazi river basin in Tanzania. Antibiotics 2020, 9, 838. [CrossRef] [PubMed]

54. Roth, N.; Käsbohrer, A.; Mayrhofer, S.; Zitz, U.; Hofacre, C.; Domig, K.J. The application of antibiotics in broiler production and the resulting antibiotic resistance in Escherichia coli: A global overview. Poult. Sci. 2019, 98, 1791-1804. [CrossRef] [PubMed]

55. Haluza, D.; Jungwirth, D. ICT and the Future of Health Care: Aspects of Doctor-Patient Communication. Int. J. Technol. Assess. Health Care 2014, 30, 298-305. [CrossRef] [PubMed]

56. Haluza, D.; Hofer, F. Exploring perceptions on medical app use in clinical communication among Austrian physicians: Results of a validation study. Health Informatics. J. 2020, 26, 1659-1671. [CrossRef] 
57. Alaiad, A.; Alsharo, M.; Alnsour, Y. The Determinants of M-Health Adoption in Developing Countries: An Empirical Investigation. Appl. Clin. Inform. 2019, 10, 820. [CrossRef]

58. Lee Ventola, C. Mobile devices and apps for health care professionals: Uses and benefits. Pharm. Ther. 2014, 39, 356-364.

59. Chase, J. Healthcare Professionals: The iPad and other Drugs-MM + M-Medical Marketing and Media. Available online: https://www.mmm-online.com/home/channel/features/healthcare-professionals-the-ipad-and-other-drugs/ (accessed on 6 July 2021). 